\title{
3. In the wake of economic reform ... new prospects for nation-building?
}

\author{
Michael Pusey
}

\begin{abstract}
Has economic reform run its course? What potential remains for the resumption of nation-building progress? Contrary to expectations, Canberra is emerging from 20 years of neo-liberalism with disciplined government, ample revenues, an effective regulative apparatus and - perhaps — the capacity for government to steer the economy towards a brighter future. These prospects are weighed against the negative impacts of neo-liberalism on our institutions and then examined from the three viewpoints of: (1) our national political experience; (2) the administrative apparatus; and, (3) popular expectations. This chapter then considers the dynamic energies inherent in the challenges, respectively, of climate change, infrastructure development, and economic policies based on the enhancement of quality of life.
\end{abstract}

\section{Introduction}

I am best known for a book sub-titled 'A Nation-building State Changes its Mind' in which I argued that the state apparatus had given up on the nation and decided to build the economy instead. ${ }^{\text {In }}$ Ine wake of a quarter century of root and branch neo-liberal economic re-engineering of a whole society it is useful to now reflect on the prospects for a renewal of nation-building.

A few comments at the outset will save time. We Australians do have a somewhat unique charter myth. Australia is a Benthamite society with a very secular, unromantic and down-to-earth utilitarian idea of itself. ${ }^{2}$ For Britons today evocations of national identity will play on 'our British heritage'. Americans will use well-developed moral vocabularies to talk about their founding rights and freedoms. Old European nations evoke their own notions of national destiny with appeals to myths of origin, to communities of descent, and to millenarian and heroic histories. Here in Australia we pushed the Aborigines aside and quickly set about constructing a nation geared to something like the delivery of the greatest good to the greatest number. Our foundation population was 'born modern' committed to Enlightenment ideas of progress and steeped in the view that society could be improved through the application of reason and industry. $^{3}$

This was never a romantic and giddy metaphysic but it did carry its own kind of unifying symbolism. Progress understood as security, as freedom from war 
and strife and, above all, as prosperity for all is - or was - our own quasi-utopian ideal. It shaped our national imagination and, right up until the early 1980s, it served to sustain and to integrate what was then a centrist two party political consensus and a full gamut of public policies aimed at building a still new nation. To catch the flavour and the meaning think to those brochures we used to attract migrants to Australia in the 1940s and 50s. All the key bits of our story are there: massive infrastructure developments (the Snowy Mountains Scheme and the like), a relaxed lifestyle, the absence of old class antagonisms, vistas of new suburban dwellings priced within the reach of the 'common man', free education for all, a vast sunny continent with unlimited potential offering improving quality of life for all. This was the Australian post-war dream. Construed in this way, nation-building may be the 'white-fella' version of The Dreaming; in short the idea of ourselves that we go on reconstructing and projecting into the future to lead our understanding of who we are.

Neo-liberalism (and the attendant phenomena of globalisation or economic rationalism) has imposed its own strictures on states and governments everywhere. But are we the only society that has surrendered its charter myths, and its images of its own future, to the dull compulsions of the markets? Or could it be that there is once again a potential for a positive, constructive, re-emergence of nation-building governance. Is there a potential to stop the tail from wagging the dog and to once again draw the markets into the service of the people? Perhaps the time is right for such questions: in Europe globalisation tends to dissolve and subsume the idea of national purpose into the larger framework of the European Economic Community. Here, by contrast, we find ourselves thrown onto our resources. We are not threatened with any national emergency or with belligerent neighbours. Not withstanding the plight of Aboriginal Australia we have no serious ethnic, religious, or social divisions. A strong national economy sustained by a resource boom offers the best prospects in a long while for mid to long-term economic stability. The Treasury is as, I heard one senior Treasury official recently say in public, 'awash with money. We hardly know what to do with it'.

So what potential might there be for nation-building to wake from 25 years of amnesia? To answer that question I want to examine the prospects for a resumption of constructive nation-building from three viewpoints: national politics; national administration; and national political culture.

\section{National politics}

First of all, we should note that we have grown accustomed to radicalism. The Whitlam government was a radical government. The Fraser government was not. But the Hawke and Keating Governments were radical in much the same way that the four Howard governments have been. As with the Thatcher 
governments, radical governments want to 'crash through' and if necessary destroy existing institutions to get their way and overcome what the reformers love to call 'institutional inertia'. And here I am reminded of a 1996 speech by Paul Keating about economic reform and institutional change in which he made a very revealing comment about his government's attitude to institutional change. ${ }^{4}$ His words were, 'If you stop pedalling the bike falls over'. He was speaking explicitly about the dynamics of change as an advocate for top-down, 'crash-through' economic functionalism. He might just as easily have said that the only way to maintain the momentum of reform is to keep the whole national population reeling on the back foot. What I heard in this justification for a general strategy were two admissions. First, he was admitting that there was no consensus for economic reform and, implicitly, that public policy deliberations are futile and a waste of political time and economic opportunity. The second presumption was that strong leaders must keep up the momentum so that all normative questions about what the people really want are always left behind, subordinated in advance to economic functions, so that they cannot effectively mobilise resistance to economic reform. How times have changed!

Libertarian, free market, laissez faire economics, economic reform, structural change, economic rationalism - call it what you will — was developed in the 1970s and early 1980s and pressed upon the developed Trilateral democracies (of North America, Western Europe and Japan) as a remedy for what was touted as a general systemic problem. These democracies were held to be drifting, rudderless, in the grip of a 'New Class' of self-serving drones, paralysed by bureaucracy, and weighed down with an overload of mutually contradictory decisions. In the words of the 1975 report to the Trilateral Commission, the problem was that these democracies had become ungovernable. ${ }^{5}$ My point is that, at least in its own terms, the Australian version of crash-through reform has done its job with a vengeance. Over a quarter of a century two ruling parties - the ALP and the Coalition - and their ministers, have demonstrated, dramatically, that they can call up massive reserves of organised power to transform a whole nation society.

Second, contemporary politics and contemporary politicians have entirely changed. In a recent article Bob Brown, leader of the Greens, ventured the view that most politicians still come to this demanding and thankless work because they want to make a difference. Yes, maybe, but if we put their values to one side for the moment I think we can see the result of a generational transformation in our career politicians - at least at the national level. The terrible work of intra-party politics, of committee work, of selling the Government's, or the Opposition's line on a whole range of policies weighs so heavily on these overworked people that they scarcely think about their constituents - except at election time when they feel a little more vulnerable. The branch party members have vanished. But there is something more: politicians no longer recognise themselves or 
understand what they do in received notions of Millean representative democracy and popular sovereignty. Collectively at least, as members of a Party, an Opposition or a Government, they no longer believe that sovereignty lies with the people. That notion has been stood on its head. For them professional, grown-up, big-league, politics is about aggregating and managing big interests. For the most part they no longer believe that it is their duty to obey public opinion but rather that it is their job - with the help of an army of media advisers and spin doctors - to bend, cajole, and manage the public into an acceptance of whatever the system can deliver within whatever parameters are set by big interests operating in an increasingly globalised economy. Grassroots, face-to-face, town-hall, and party branch-based democracy of the post-war and later Whitlam times is now eclipsed as a motive force for big politics. Political communication is done through the Media. My point then is that nation-building could only make sense to this generation of professional politicians as a tightly managed top-down process.

Third, for a quarter of a century both major parties have been wedded to a politics that sits in outright contradiction with our national history. Our tradition is one in which the state led and private capital followed in close partnership. Butlin reminds us that from our very beginnings a pattern of reliance on public investments as the driver for development 'became so entrenched that it was not until the 1930s that private capital investments exceeded public capital outlays - and they still accounted for just over one third of total capital formation in the 1970s' ${ }^{6}$ From the time of Prime Minister Hawke's 'trilogy' commitment of 1984 we have been subject to an aggressive application of a doctrine that John Braithwaite has so exquisitely labelled the 'hydraulic model' ${ }^{7}$ It proceeds from the same libertarian American ideology that drives neo-liberal free market economic reform and assumes that to have strong markets you must have weak states. Our two major parties seem committed to this renunciation of our past with the application of policies that are deeply averse to public spending and which assume - in the face of all the contrary evidence - that the state sector is a national burden, a hindrance to development, and that a dollar spent in the private economy is a productive dollar and worth more than a dollar spent in the public sector. Our politicians do not wish to recognise that the libertarian Anglophone variant of modern capitalism shows up poorly even on conventional economic criteria of comparative economic performance. ${ }^{8}$ I can think of no other developed nation whose politicians have so completely abandoned their institutional inheritance to a foreign ideology.

Fourth, in the wake of a now defeated Australian settlement both major parties believe that they must accede to the demands of a corporate business sector that operates in a changed relationship to the Nation. The destroyed Accord between the Labor government and the unions marked the end of a century of what the political scientists called 'corporatism': namely government through a cooperative 
three sided partnership, brokered by the State, between Capital and Labour. Now faced with a globalised multi-national corporate sector, politicians no longer believe that they can do much to moderate the raw elements of the broader economic dispensation within which the people must live their lives. The comparative evidence so clearly shows that different nations adapt to the same global economic forces in very different ways - in many cases with strongly positive outcomes for their national populations. ${ }^{9}$ Yet our politicians have decided that governments of either persuasion must first of all serve a Business Council (the CEOs of the top 100 corporations) that always makes the same demands: namely, for a predictable environment for investment; for the minimum attainable price for labour; and for the minimum attainable level of corporate taxation. The national accounts tell the story. Over the 20 years from 1980 to the year 2000 the total wages share fell from $60 \%$ to $54 \%$ as the profit share rose from $17 \%$ to just on $24 \%$. The government share stayed at about the same low level. And the trend continues. The point is that nation-building in any form that costs a lot of money cannot happen unless the Business Council will allow it to happen.

Through this window into national politics we see mixed prospects for a resumption constructive nation-building. On the one hand, there is clear evidence that national governments can govern strongly and effectively. Yet this was done in the name of neo-liberal economic restructuring of a whole nation society. Could this newfound strength be used over the longer term to re-build our infrastructure and to draw the markets and major corporate interests into the service of a more progressive and inclusive future for 'the Nation'? Is that what a Rudd government will try to do? We don't know.

\section{The Canberra bureaucracy and the federal structure}

The first point I want to make is that the top Canberra public service has turned its back on nation-building. This is so important because we have known since the early '70s that, in developed nations, top public servants are typically, with their ministers, the co-authors or even the originators of national policy. Now the neo-liberal economic rationalists dominate Canberra. We are a light year away from the Coombs 1976 Royal Commission on Government Administration which recommended that Treasury should be stripped of much of its power and that economic policy-making be largely devolved to the line or spending departments in order to gear it more closely to the real, coal-face, economic and social priorities of nation-building. In 1991 the findings reported in Economic Rationalism in Canberra showed that power was instead concentrating in the central agencies of the Department of the Prime Minister and Cabinet, The Treasury and the Department of Finance and Administration. ${ }^{10}$ An older generation of broadly experienced and more broadly educated small L liberal and Fabian intellectuals - most of them with degrees in humanities, social 
science and the law - were losing out to a new elite of younger, dry, narrowly-trained, neo-liberal economists who were, from the early 1980s, being reeled up into the central agencies through the mechanism of accelerated promotion. From the first Hawke-Keating years, the Public Service Board quickly lost its independence. The very idea of a Career Service charged with giving advice 'without fear or favour' was put to the sword as top public servants were brought to heel, put on short-term contracts, told to perform and to do the ministers' bidding or risk losing their performance pay and all hopes of further advancement.

As they say 'the rest is history'. The post-war generation of committed centrists and progressively minded improvers and nation-builders with longer time horizons were overwhelmed in an ideological restructuring, a political re-education if you prefer, of the top federal public service. In 1992 Coombs, himself a former Governor of the Reserve Bank of Australia, was not shy in venturing the judgement that 'the intellectual and moral basis of Australian society is being corrupted' and that 'the driving force behind [these reforms] is a view of the economy as a machine independent of social purposes'. Today public policy is set within an ideological mould that is, at least in principle, averse to public expenditure, to public borrowing, to what we used to call the 'mixed economy', to planning per se and to the deployment of state power to steer the national economy into any kind of mid and long-term nation-building initiatives. Not surprising then that John Wanna and his colleagues should conclude that, after 20 and some years of these reforms, Australia has a system of public expenditure that is averse to capacity building and for which 'budget rationing rather than budget maximising has become the Australian creed' ${ }^{11}$ This is a culture that is likely to prejudge nation-building initiatives as reckless adventures and to shun large publicly funded infrastructure projects and capacity building.

My second point is that we have a demonstrably efficient and professional bureaucracy. Despite occasional lapses into the overt politicisation of elements of public administration, there is no evidence of systemic corruption. The streamlining of the forward estimates, accrual accounting, new information technologies and the increasing sophistication of Department of Finance and Administration controls on expenditure have all contributed to huge gains in the efficiency of a Canberra public service that is half the size of 20 years ago. ${ }^{12}$ The forced mobility of senior public servants across different program and policy areas has, with strong central agency coordination, produced a loss of corporate memory and of hands-on experience in dealing with specific program areas. At one point in the early 1990s there were at most one or two Senior Executive Officers in the then Department of Education with any expert knowledge of schools and education. Most of them were drop-in economists, accountants and managers from other areas focussed only on coordination and efficiency. On the 
other side of the coin these reforms have given the lie to the 'new right' dogma that bureaucracies and governments are inherently unable to cope with the complexity of coordinating national affairs. The bureaucracy has proven that it can forecast and control expenditures accurately, that it can respond flexibly to changed funding priorities and that it can, perhaps, effectively coordinate policies across and between departments rationally and efficiently. ${ }^{13}$ Although the experience of nation-building has been long forgotten, the capacity to coordinate major initiatives over time and perhaps across several departments is probably much stronger that it ever was.

Thirdly, we have new tools for pro-active nation-building. Let me briefly mention three of them. John Braithwaite explains that tax collection from multi-national corporations has increased at about three times the growth in GDP and that this is largely the result of new information technologies. It is clear that IT systems and our experience in learning how to use them have greatly augmented the capacity of government to plan and monitor programs and initiatives. Another cause for optimism appears when we look past the shibboleths about deregulation to the real story. True, the deregulation of the financial sector led to profiteering by the banks and contributed to unsustainable levels of private indebtedness and an artificial inflation of house prices. The partial deregulation of the labour market and, most egregiously, 'WorkChoices', has produced another type of sponsored exploitation. In other areas, however, we see not free-for-all laissez-faire deregulation but, instead, the emergence of what Braithwaite calls a 'regulatory capitalism' that is extending and deepening regulatory supervision across a range of public and private industries with amazing speed. ${ }^{14}$

In the interests of creating a more predictable future, business is more often inclined to accede to public calls for governments to provide sound publicly enforceable safety, prudential, environmental and ethical standards for corporate activity. Improved regulation also has the demonstrated potential to turn privatisation into a good news story. For example if the government can impose suitable standards for telephony and broadband spectrum usage on a fully privatised Telstra then the revenues from the sales of government equity in such enterprises can be used for other purposes.

It is worth noting that some 25 years ago we had scarcely heard about accountability or about targeted or performance based funding. We are now much more able to make public administrative and financial systems deliver on their promises. For example, ongoing British reforms of the National Health Service under Blair have used targeted funding and improved efficiencies in the delivery of health care to eliminate queues for elective surgery in British hospitals. In short the available instruments for the delivery of nation-building have vastly improved from the days of post war reconstruction and the Whitlam governments. 
Fourthly and more worrying are the challenges to nation-building that accrue from our creaking federal system. The year 2007 should be remembered as an example of an especially glaring dissociation and imbalance between the state and federal levels of governments. On the one hand, the 2007 election gave us a picture of a national government awash with revenues as our two major political parties were forced into a perverse and ideologically sponsored competition to see which would better squander a once-in-a-lifetime opportunity to build a modern national infrastructure by handing back tax revenues in electoral bribes. On the other side of this canvass we find a NSW Labor government selling off precious coastal forest land to pay for improvements to a rail and public transport system that is in ruins from decades of neglect, incompetent management and chronic under-funding. Similarly we have seen the Queensland and NSW governments locked in competition to grant unsustainable water licences to their own up-stream water users at levels that are seriously endangering our principal national river system.

Three observations will suffice to point to the magnitude of these problems. In the first place, and in contrast with other federations like Canada, we suffer from a mighty fiscal imbalance between a federal state that collects some $75 \%$ of all revenues and a state sector that is still constitutionally responsible for the lion's share of service delivery and public works. Secondly and less obviously we see that the national press gallery of some 200 and more Canberra based journalists does a reasonably good job in scrutinising the actions of the federal government. By contrast, at the state level, which carries the major share of constitutionally assigned responsibility for public works and service delivery, there is so little scrutiny that successive NSW government have been allowed to get away with such egregious blunders as the bungled funding of the Sydney Cross City Tunnel, the desecration of east Circular Quay, the commissioning of unserviceable train rolling stock and, most recently - and in the face of the best advice - the go-ahead for the Sydney Water desalination plant. What is more, in this environment regional policies that involve still more problematic inter-government cooperation are virtually impossible. Thirdly we hear many experienced administrators telling us that divided state/federal responsibility for the delivery of services nearly always results in buck-passing and failures of coordination. The provision of pharmaceuticals in public hospitals and most recently the fraught attempts of federal government to intervene in Northern Territory Aboriginal policy are but two examples of these failures. Divided responsibility generally fails and it greatly impairs our capacity to mount nation-building initiatives that mostly intrude into state jurisdictions and require a concerted whole-of-government approach.

In conclusion (to this second section) it would seem that in the wake of 20 and more years of neo-liberal re-engineering of the machinery of government we have a more technocratic and managerially oriented top federal public service 
with an ingrained ideological aversion to nation-building and a much reduced capacity for delivering fearless and independent advice to ministers. On the other side of the coin there have been huge gains in efficiency, budget management and coordination. Yet, even in the face of an increasingly dysfunctional imbalance between federal and state levels of government, we find some encouragement in the observations of Wanna and others that the federal government has shown itself increasingly capable of directing and monitoring expenditures, even in areas that are outside its formal jurisdiction. ${ }^{15}$

\section{Our national political culture}

What has happened to our memory of nation-building post-war government? How does an earlier history of nation-building shape the norms and standards that we apply to contemporary politics and to our assessments of a 25-year-long experience of economic reform?

We have not given up our expectations of what good government can achieve. First there was the floating of the Australian dollar and then the deregulation of the capital markets. Then privatisation, labour market reform, micro economic reform, user pays, cutting government spending, competition policy, more labour market reform (WorkChoices) and the push for the privatisation of Medicare. All of these reforms were pressed on us with the same unrelenting message. Government is a blunt instrument and for the most part the enemy of progress and prosperity. Taxation is a form of theft. We should rid ourselves of the Nanny State, expect less of governments, become a shareholder society, and rely instead on the creative energies of private enterprise and free market capitalism. Australians were urged to accept the new doctrine 'that economies, markets and money would always, at least in principle, deliver better outcomes than states, governments and the law'. ${ }^{16}$

Have we bought this message? The evidence shows that we value efficiency and want a well functioning economy but that we do not want economic considerations to one-sidedly redefine or restrict the role of government. Take a glimpse at the evidence. My Middle Australia interview surveys of 1996 and 2000 included a question asking whether respondents thought that governments, of whichever party, could do 'quite a bit' or 'very little' to effect change in 13 domains labelled as follows: 'to keep prices down', 'to reduce unemployment', 'to improve general standards of living', 'to improve health and social services', 'to reduce poverty', 'to cut crime', 'to make business pay fair wages', 'to create more job security', 'to support families, to reduce the gap between rich and poor', 'to control economic change', 'to hold society together', and 'to support communities'. The results show that an average of about $70 \%$ of middle Australians believe that governments can do 'quite a bit' across this broad range of functions. We are not, and never have been, gung-ho libertarians. Clearly 
Australians have resisted the new doctrines and still expect effective proactive governments to steer economic development.

Australia has not accepted institutional reform. In the midst of the economic boom and in the wake of relentless attempts to persuade them to the contrary the Middle Australia respondents believe that the nation was better served by the older post-war 1945 to 1985 institutional order than it is by the newer, reformed, institutional order that has been foisted upon them with economic reform. While not denying the need for change, over half of the respondents believed that the older economic institutions including industrial awards and national wage fixation, had brought 'only benefits' or 'more benefits than harm'. Our review of the data from the much larger 2003 Australian Survey of Social Attitudes (AuSSA) showed that two thirds of us believe that 'awards and wages are the best way of paying workers and setting conditions'. Only $29 \%$ of Middle Australians expressed support for economic reform defined as 'the deregulation of business, competition and privatisation'. Again these findings are consistent with the 2003 AuSSA survey showing that only about $10 \%$ of respondents approved selling off major services to private interests. What we see revealed in these several findings is are our own preferences for an older institutional order that has defined the nation virtually since federation and which has shown itself to be remarkably resilient even in the face of saturating elite attempts to win credibility and legitimacy for the new neo-liberal dispensation.

We have clung steadfastly to our inherited belief that states, business and trade unions should work together, collectively, to build a fair, secure and prosperous future. My own Middle Australia data accords with the findings of numerous surveys, including the comprehensive Australian Electoral Studies (AES), showing that nearly three quarters of us believe big business has too much power. ${ }^{17}$ Conversely the AES survey shows that the number of people believing that trade unions have too much power has been falling steadily for 30 years to a minority today of only $41 \%$. Interestingly, in the 2005 Australian Survey of Social Attitudes we hear a huge $76 \%$ of respondents agreeing with the proposition that 'when big businesses break the law they go unpunished'. About $60 \%$ thought that the federal government is run not for 'the benefit of the people' but entirely, or mostly, 'for the benefit of a few big interests looking out for themselves'. The AES survey put the number at $67 \%$ in 2004. My Middle Australia study shows that middle Australia is interested in politics and cares about 'the Nation'.

Australians think about the distribution of power from within a normative framework that is linked to their perceptions and concerns about the distribution of income. An ever-larger proportion of Australians also want to see a more equitable distribution of income and wealth. The Middle Australia survey asked whether respondents thought that 'the incomes and job prospects of middle Australians were rising or falling'. In 1996 two-thirds of our respondents said 
that income and job prospects were falling and, strikingly, as the economy settled further into boom conditions, the number of people saying that wage and salary earners were the losers from economic reform rose by some 13 percentage points to $70 \%$ in the year 2000. My own and several other studies show that people do not think this distribution is fair and that those judgements are quite tightly related to differences in income. Successive national surveys show the proportion of Australians who thought that income differences were too large has grown from $62 \%$ in 1984 to $84 \%$ in $2003 .{ }^{18}$ In reviewing these and other findings in the light of the AuSSA 2003 survey Nick Turnbull and I were struck by the unwavering two thirds majority support that Australians give to the Award and Arbitration system which they see as the fairest way of setting levels of pay. Here, specifically with respect to the distribution of power and income, we see manifest a re-affirmation of an enduring, historically conditioned preference for the same bedrock structure of power and income distribution that was set in place at Federation and which has ever since defined the political economy of our nation.

\section{Preliminary conclusions}

Now to some preliminary conclusion on the prospects for a resumption of nation-building. First of all there is the obvious point that nothing can happen unless governments make it happen. And here the news is probably good. Canberra has demonstrated that it can call up massive reserves of power to change the course of national development. In the wake of these changes it is likely that government has less leverage over wages and monetary policy and less room in which to moderate the demands of the corporate sector. But we do have ample revenues and, probably, a hugely more efficient Canberra administrative apparatus with a freshly demonstrated capacity to deal coherently with the immense complexity of modern government.

The aim of a 25-year-long, top-down, neo-liberal re-engineering of a whole nation society was always to drive the market ever more deeply into the grain of daily life as a denominator of value and an automated code for all significant life decisions. The market was meant to bury deliberative politics, to reduce popular expectations of government, to redefine politics as economic management tout court and to neutralise normative culture. To use Francis Fukuyamas' phrase, it was meant to bring us to the end of history and even to kill the shaping influences of memory and history in national politics. Had it succeeded Australia would feel more like Singapore and 'the Nation' would be dead as a motive force in our lives. But thankfully it has not succeeded. A certain pragmatic utilitarianism is still actively shaping our imagined future, our intuitions and value judgements about fairness, and about what progress and national development should mean: and we care about it. Our own 'Whitefella Dreaming' might still be working on our collective will and imagination. 
With four final points I hope to persuade you that the changed nature of the challenges we face in the future may come to the rescue of our nation-building past.

Firstly, it is likely that a constructive adaptation to global warming will give rise to structural and cultural changes of a kind that we last saw in the aftermath of World War II. Economic history teaches us that War transforms the relations between economy, political culture and the state. In our case World War II brought on a permanent concentration of income tax powers at the national level, a still ongoing program of mass emigration of new settlers to our shores, and a spate of iconic nation-building programs like the Snowy River scheme. These are iconic elements in our own version of the 'Dreaming' that keep alive our hopes for nation-building. ${ }^{19}$ Facing up to global warming has the potential to resuscitate our national imagination in a similar way. It presents us with challenges that obviously call, not only for incremental changes at the household level, but also for whole-of-government action at the national level. Here we need think only of what will be required to bring the Murray Darling river system back to life in a future of reduced and more variable rainfall. This challenge alone has the potential to break up much of the rusted, stalemated, framework of current federal-state relations: think of the implications, not just for allocation and the pricing of water, but also for a whole clutch of related and interconnected changes that will redefine water conservation, forest management, primary industry, farming practice and rural and regional development. It even has the potential to heal the tragic gulf that now divides urban from rural Australia. 20

Changes on this scale are likely to burst the limits of routine pragmatic political accommodation. They force appeals to a latent collective national imagination and so take on an iconic force that can change motivations and bring people together with an enlarged sense of collective agency and identity. With this could come a restored sense of sovereignty and political agency. So also global warming might give us an opportunity to mobilise power in a way that brings vested interests to heel. More fundamentally, it has the potential to restore the legitimacy of state intervention and to generate the needed cultural energy for nation-building government - those very resources that our economic reformers have tried so hard to erode! It creates spaces in which strangers can more easily recognise each other as citizens of the nation joined in mutual responsibility for the longer-term future that they will bequeath to their own children. Of course all this could be so easily sidelined. My point is simply that the challenge of global warming has the potential to produce some very powerful nation-building proteins.

A second creative challenge has to do with the re-building of our infrastructure. We are members of the OECD with a per capita national income that is about 
the same as France. France has a first-world national transport and rail network: ours is not much better than India or, at best, Malaysia. We have some of the world's most liveable cities that are being stressed by bad public transport and the absence of all coherent planning. The same is true at every level of our run-down education system. Ditto for our broadband capability and for our investments in research and development in new technologies and value-added quality niche manufacturing. Look out from the breakwater at Newcastle harbour and you will see (on my last visit there) up to 52 ships waiting to load coal from our hopelessly outdated loading terminals. The point is, simply, that our infrastructure deficits are huge, glaringly incommensurate with our aspirations as a first world nation - and, that, now, for once in a lifetime, we have both the revenue and compelling economic justifications for doing something about it. Huge reconstructions change expectations, create opportunities and fire up the national imagination.

Third, it is a commonplace of political sociology that progressive and modernising social movements - of which the women's movement, the peace movement, and environmental and conservation movements are the most notable instances - can only make way in the face of organised political power when entrenched opposing interests are in disarray. The point is that, in Australia today, at the level of ideas, the neo-liberal opposition to constructive governance and nation-building is eclipsed or even exhausted. No one is listening anymore to the worn out ideological catch calls for more privatisation, user pays, cutting government spending, smaller government, and more competition: and perhaps likewise, thankfully, labour market reform. For the moment at least the vested interests have lost their voice. It takes a lot of energy and a long time - maybe 20 or 30 years - for selfish power to persuade national populations to accept policies that are opposed to their larger national interests. And even then it can take a comparatively short time for the ideologies to come undone and for the people to come to their senses. There is a good chance that even blind ideological objections to public borrowing could be swept away by renewed political calls for constructive nation-building.

With the fourth and last point I come to the prospect about which I care most. My survey of middle Australian attitudes showed that even 10 years ago there was no consensus for economic reform and, more to the point, that the broad middle was waking up to the realisation that more economic reform meant more pressure on families, run down public health and education services, less job security, more stressful workplaces, urban degradation, uncertain retirement incomes, and probably declining whole-of-life incomes. Later national survey numbers confirm that an increasing proportion of us are seeing, for the first time, that more economic reform also brings reduced standards of living for our children. It is a perfect example of what some people call 'social learning'. Intuitively, and ever more consciously, a national population may just be waking 
up to the truth that a booming economy and increasing GDP means environmental degradation, endangered futures and falling quality of life. And with that awareness comes a recognition that 'the Economy' is not animal mineral or vegetable, not a thing in itself, but a symbolic construction that comes out of society itself as a political artefact and something that we have the power to change.

As that understanding sinks in a nation can more easily understand for itself that economic rationalism is a perfect irrationality, an ideological concoction, and a form of systematically distorted communication. We see then that we must again understand and use the economy in exactly the same way as our great 'Nugget Coombs' generation of nation-builders did, namely as a set of practical instruments for improving the lives of a national and now global population. What is the use of money if it makes you poorer? That unsettling question has the potential to change the meaning of money. I think I hear that bit of the story coming at us like a steam train in a tunnel.

Here we are at the end. Of course, there are no metaphysical or historical guarantees. Still, I put it to you that the prospects for a resumption of constructive nation-building are better than they have been in a long while.

\section{Acknowledgements}

In preparing this chapter I have been greatly helped by several friends and dialogue partners. My thanks go to John Braithwaite, Tim Rouse, John Wanna, John Butcher, Adrian Fordham and Ian McAllister, among others.

\section{ENDNOTES}

${ }^{1}$ Michael Pusey, Economic Rationalism in Canberra. A Nation Building State Changes its Mind, Cambridge University Press, 1991.

${ }^{2}$ Hugh Collins, 'Political ideology in Australia: The distinctiveness of a Benthamite society' in Australia: The Daedalus Symposium, ed. Stephen Graubard, Angus and Robertson, Sydney, 1985.

3 John Gascoingne, The Enlightenment and the Origins of European Settlement in Australia, Cambridge University Press, 2002

4 Paul Keating speaking on Social Policy at the University of New South Wales, 11 November, 1996

5 Michel Crozier, Samuel P. Huntington and Joji Watanuki, The Crisis of Democracy, Task Force Report no. 8, New York University Press, New York, 1975.

6 N.G. Butlin, A. Barnard and J.J. Pincus, Government and Capitalism: public and private choice in twentieth century Australia, Allen \& Unwin Sydney 1982 p 320-322

7 J. Braithwaite, 'Institutionalising trust: Enculturating distrust', in V. Braithwaite and M. Levi eds, Trust and Governance, Russell Sage, New York, 1998.

8 L. Mishel, J. Bernstein, S. Allegretto, The State of Working America 2004/2005, Economic Policy Institute, Cornell University, 2005.

9 Francis G. Castles, The Working Class and Welfare: Reflections on the Political Development of the Welfare State in Australia and New Zealand, 1890-1980, Allen \& Unwin. 1985.

10 Michael Pusey, Economic Rationalism in Canberra. A Nation Building State Changes its Mind, Cambridge University Press, 1991.

11 John Wanna, Joanne Kelley and John Forster, Managing Public Expenditure in Australia, Allen and Unwin, 2000, chapter 12 . 
12 Andrew Leigh, 'Reinvigorating the Australian Project', Garran Oration, RSSS, ANU, Canberra, Australian Journal of Public Administration, 64(1) 3-7. March 2005.

13 John Wanna and his colleagues seem to say that horizontal coordination across different departments is working more efficiently while other reports - CAEPR Working Paper No. 36, CAEPR, CASS, ANU, Canberra - suggest, for example, that coordination across departments in the area of indigenous affairs has generally failed.

14 My thanks to John Braithwaite for sharing with me a chapter, entitled 'Neo-liberalism or regulatory capitalism?' of his forthcoming book on this subject.

15 See Wanna et al.

16 This is one of two definitions of 'economic rationalism' that I put forward in the so-called 'economic rationalism debate' that exploded with the publication of Economic Rationalism in Canberra in the early 1990s. The other is that 'economic rationalism is a doctrine which says that, 'the market is, at least in principle, the only means of setting values on anything'.

17 Trends in Australian Political Opinion; Results from the Australian Electoral Study, 1987-2004 Ian McAllister and Julliet Clark.

18 M. Pusey and N. Turnbull, 'Have Australians Embraced Economic Reform?' chapter 10 in Australian Social Attitudes. The First Report, (eds.) S Wilson et al, University of New South Wales Press, 2005.

19 My friend John Carroll, a conservative cultural theorist, says that the Aboriginal idea of "The Dreaming' is our best theory of culture. It certainly solves a problem that I have never known how to handle. With every historical reference to a remembered past I am accused of being a 'Golden Age' apologist who wants to turn the clock back to 1950s - an accusation that I vehemently reject. So how to speak of the past without opening yourself to accusations that you are 'essentialising' it?

20 Kenneth Wiltshire, Tenterfield Revisited, Reforming Australia's system of government for 2001, Queensland University Press, 1991, p14. 